\title{
Coping Strategy and Psychological Well-Being of Final Year University Student
}

\author{
Yuni Syaudab ${ }^{1}$ \\ ${ }^{1}$ Department of Psychology, Universitas Negeri Yogyakarta, \\ Jl. Colombo No. 1 Karang Malang Sleman, Yogyakarta \\ 1yuni.syaudah2015@student.uny.ac.id
}

\begin{abstract}
This study aims to determine the coping strategies and level of psychological well-being of final year university student, as well as predicting psychological well-being of final year university student based on their coping strategies. This study employs quantitative approach with ex post facto research type. This study involves 135 university students from Faculty of Education Universitas Negeri Yogyakarta by means of accidental sampling technique. Data was collected through the coping scale (problem focused coping scale and emotional focused coping scale) and psychological well-being scale. The result of this study shows that coping strategy was able to predict psychological well-being $(\mathrm{p}=0,000 ; \mathrm{p}<\alpha 0,05)$. Problem focused coping and emotional focused coping can predict psychological well-being by $12 \%$. The regression equation line obtained is $\mathrm{Y}=$ $132,05+0,819 x 1-0,501 \times 2$
\end{abstract}

Keywords: problem focused coping; emotional focused coping; psychological well-being; final year university student

\section{Introduction}

The higher the level of education pursued, the higher the level of stress experienced (Calnicer and Calderon, 2013). From these statements it can be seen that a person pursuing higher education may experience the highest stress level. University students will be challenged with more demands compared to the previous educational level, the workload will also be heavier as they proceed through the years. Indonesian bachelor (S1) students who have reached their final year, will eventually have to work on their final project or a thesis.

Doing thesis for final year students is not an easy thing. In fact, there are students who feel burdened and experience various difficulties in working on their thesis. Difficulties in the preparation of the final thesis are also felt by students of the Faculty of Education (FoE), Universitas Negeri Yogyakarta. Based on the results of interviews with several $\mathrm{FoE}$ students, it is revealed that final thesis is considered as a stressful work. Some students start to encounter difficulties or problems as they worked on their thesis. Some of the problems presented includes difficulties in various stages of the thesis: difficulties in fighting laziness, gathering enthusiasm, determining the right topic, working on their introduction chapter, finding references, finding respondents, data collection, and data analysis. Other challenges includes difficulties in arranging a meeting with their supervisors, lack of encouragement and guidance from supervisors, fear of meeting with supervisor if they have no progress in their thesis, idea differences between the supervisor and the students, revision by the supervisors, and the difficulty of finding the middle ground between the student and the supervisor. These difficulties will lead students to experience stress (Astuti \& Hartati, 2014).

Studies by Ryff (1995) shows a significant relationship between stress and psychological well-being. Ryff (1995) 
argued that to achieve a good level of psychological well-being, individuals should be able to cope with stress and avoid mental health problems. Psychological well-being refers to the extent to which individuals feel that they have meaningful control over their lives and activities.

Problem in psychological well-being is becoming increasingly common among students today (Yang, 2010). High levels of stress have been reported among students from various departments in higher education institutions (Mackenzie and Kim, 2011). Some of the causal factors associated with problems among students are uncertainty about their career and future success, as well as academic stress, one of which is thesis (Ibrahim et al., 2013).

However, we should understand that stress is not only have negative effects, but stress can also have positive effects. This experience will depend on how an individual deal with their problems (Preece, 2011). This indicates that coping can affect psychological well-being.

Coping can be defined as thoughts and behaviors that are used to manage demands on internal situations and external situations that are considered as stressors (Taylor, 2011). Coping strategy is an effort, both behavioral and psychological, employed by an individual to master, tolerate, reduce, or minimize the impact of stressful events (Kenneth \& Pakenham, 2012).

Each student working on their thesis will have different coping strategies. Lazarus and Folkman (1984) explained that an individual's maturity is related to their coping abilities. Deciding on which coping strategies used may be based on the stressful situation that they're currently faced. Those who can adjust their coping strategies to match their situations, will have a better chance to deal with stress compared to those who cannot (Taylor, 2011).

Forms of coping include diverting attention to other activities that are not related to the thesis (such as playing games, watching football, watching movies, sleeping, and reading other books not related to the thesis), praying and doing religious activities such as Dhuha prayer and tahajud routinely, add knowledge on how to write scientific papers, add new experiences and find new insights in how to write, find references to the latest books by title, try to discipline time in all matters, join friends and share information, look for convenient time and place to finish the thesis, and think positively (Ismiati (2015). Related to this, it can be seen that in facing the thesis, there are some students who choose to face it and some are avoiding. Students who avoid sometimes because they have not able to determine the right coping to deal with stress experienced.

Previous research states that coping strategies are related to psychological wellbeing. Some types of coping are more effective than others in maintaining psychological well-being. Facing the problem will better maintain the level of psychological well-being compared to avoidance coping or avoidance of the problem (Calnicer and Calderon, 2013). Individuals who can provide an appropriate response to the problems faced, even though he is in a state of stress will affect the level of psychological well-being of the individual (Calnicer and Calderon, 2013).

From the explanation above, it is known that how students handle stress or coping will affect psychological well-being. Researchers do not measure stress levels on students, but researchers will conduct research on how students deal with stress experienced. Therefore, important research is conducted to determine the effect of coping on psychological well-being in the final year students who are working on thesis. Researchers want to study in a study entitled "Coping and Psychological Wellbeing Strategies for Final Year Students". Researchers assume that coping conducted by final year students can affect the psychological well-being of students. 


\section{Coping Strategy and Psychological Well-being Yuni Syaudah}

The purpose of this research is to find out the coping done by the final year students who are working on their thesis, know the level of psychological well-being in the final level students who are working on their thesis, and predict the psychological well-being in the final year students who are working on their thesis in terms of the coping strategy which is conducted.

This research is expected to be an additional reference related to coping conducted by final year students. In addition to adding references about psychological well-being in final year students who are working on thesis. This thesis is also expected to be able to increase knowledge for other final year students in maintaining psychological well-being with coping strategies which can be used as material for consideration to provide action or treatment for stressed final-level students in working on their thesis.

\section{Methods}

\section{Research Design}

This research uses a quantitative approach with the type of research used is ex post facto. Ex post facto research aims to find things that cause changes in the overall independent variables have occurred.

\section{Participants}

The research subjects in this study were the final year students of the 2015 Faculty of Education, Yogyakarta State University. Data collection techniques using nonprobability sampling, namely accidental sampling. Accidental sampling was chosen because the final year students had not gone through lectures in the classroom. The number of samples in this study were 135 students.

\section{Research Procedure and Intruments}

Data collection techniques used in this study is to use a psychological scale.
The instrument used in this study was to use a coping strategy and psychological wellbeing scale in the form of a Likert scale.

Data collection instruments will be delivered in person and online. Coping scale consists of 38 items with a problem focused coping scale of 15 items and emotional focused coping of 23 items. The psychological well-being scale consists of 42 items. So that there are a total of 80 items. The scale of this research instrument is in the form of four alternative answers, which are very inappropriate (value one), not appropriate (value two), appropriate (value three), and very appropriate (value four).

This research instrument includes items that are favorable and unfavorable. Items that are favorable have a value that moves from the value of one to four. While items that are unfavorable have a value that moves from a value of four to one.

\section{Data Analysis}

Descriptive analysis is an analysis used to provide a clear description related to the characteristics of the data that has been obtained, as well as certain centralization measures that provide an overview of the research conducted. Data that has been obtained from the scale of psychological well-being and coping is still in the form of ordinal data consisting of categories that are very inappropriate, inappropriate, appropriate, and very appropriate. These categories will be changed into interval data.

\section{Analysis of Prerequisite Tests}

The prerequisite test used to test the analysis is the normality test carried out to find out whether the research data is normally distributed or not. The normality test in this study uses the Kolmogorov Smirnov test with the help of SPSS for Windows. Data are stated normally distributed when having $\alpha \geq 0.05$ (Ghozali, 2018: 167). 


\section{Coping Strategy and Psychological Well-being Yuni Syaudah}

Hypothesis testing

Hypothesis testing is done after the research data has been analyzed and meets the analysis prerequisite test. Hypothesis testing in this study is to use multiple linear regression analysis test. Multiple linear regression analysis is used because the research aims to predict or predict two predictor variables against one criterion variable $(\mathrm{Y})$.

\section{Findings and Discussion}

\begin{tabular}{lccr}
\hline \multicolumn{1}{c}{ Category } & Freq & Percentage \\
\hline Very High & $\mathrm{X}>48,75$ & 23 & $17,04 \%$ \\
High & $41,25<\mathrm{X} \leq 48,75$ & 72 & $53,33 \%$ \\
Average & $33,75<\mathrm{X} \leq 41,25$ & 32 & $23,70 \%$ \\
Low & $25,25<\mathrm{X} \leq 33,75$ & 8 & $5,93 \%$ \\
Very Low & $\mathrm{X} \leq 25,25$ & 0 & $0 \%$ \\
\hline Total & & 135 & $100 \%$ \\
\hline
\end{tabular}

\section{a. Problem Focused Coping}

Data that has been obtained is presented in predetermined categorizations. Here is the categorization of problem focused coping.

Based on the table above, it can be seen that the frequency is mostly in the high category $(41.25<\mathrm{X} \leq 48.75)$ with 72 students $(53.33 \%)$. The frequency is at least in the very low category $(X>25.25)$ with a percentage of $0 \%$.

\section{b. Emotional Focused Coping}

Data that has been obtained is presented in predetermined categorizations. The following are emotional focused coping categorizations.

Based on the table above, it can be seen that the frequency is mostly in the medium category $(51,725<\mathrm{X} \leq 61,875)$ with a total of 75 students $(55.56 \%)$. The frequency is at least in the very low category $(X \leq 41.575)$ with a percentage of $0 \%$.

\begin{tabular}{llcr}
\hline & Category & Freq & Percentage \\
\hline Very High & $\mathrm{X}>72,025$ & 9 & $6,67 \%$ \\
High & $61,875<\mathrm{X} \leq 72,025$ & 48 & $35,56 \%$ \\
Moderate & $51,725<\mathrm{X} \leq 61,875$ & 75 & $55,56 \%$ \\
Low & $41,575<\mathrm{X} \leq 51,725$ & 3 & $2,22 \%$ \\
Very Low & $\mathrm{X} \leq 41,575$ & 0 & $0 \%$ \\
\hline Total & & 135 & $100 \%$ \\
\hline
\end{tabular}

Discussion

The results show that there is no difference in the ability to recognize depression and schizophrenia based on the gender of respondents and character in the vignette. The results of the study revealed different results from most of the previous studies which suggests that women have better recognition abilities compared to men (Reavley, McCann, \& Jorm, 2012; Cotton, et al., 2006; Gibbons, 
Thorsteinsson, \& Loi, 2015). However, this study is in line with the results of the study of Marcus and Westra (2012) which states that there are no striking differences in terms of recognition and general mental health knowledge between men and women.

The results are also not in line with the opinion of Hadjimina and Furnham (2017) which states that there are differences in recognition of mental disorders among male and female sufferers because some mental disorders have different prevalence in the two genders. For example, depression will be recognized more in female figures because the prevalence of depression is higher in women. Based on Hadjimina and Furnham (2017) assertion, we conclude that the lack of recognition for differences between male and female figures can occur because both versions of the vignette have the same description except the use of the name Budi and Bunga and the lack of depictions of situations that are more prototypically "masculine" or "feminine". For example, by including a description of the loss of interest in the hobby of sewing in women.

The absence of gender differences in recognition ability can also be influenced by the level of education of respondents (Bener \& Ghuloum, 2010), experience of contact with people with mental disorders (Lauber, et al., 2003), campus environment that stimulates more talk about mental disorders, mental health campaigns, also the media depiction that revealed mental disorders as a condition that can be experienced by anyone. The wider internet coverage and more openness of men to their health problems on the internet (Ellis, et al., 2013) can also be a realization that it is no less important for men to have awareness about mental health.

The second result is about differences in the identification of causes of mental disorders based on the gender of the respondents showing that there is no difference in the identification of causes of depression and schizophrenia based on the gender of the respondents. However, there are differences in the identification of causes of depression based on the gender of vignette figures.

Environmental factors and trauma are more clearly identified as causes of depression in female characters while biological factors and personal weaknesses are more pronounced in male figures. Respondents think that personal weakness is a cause of depression for men and this can be due to the existence of male gender roles which require them to be aggressive, physically and emotionally strong (Wong, 2016). Men who deviate from these expectations will experience interpersonal and intrapersonal conflicts. Therefore, showing emotion and mental helplessness is considered a form of personal weakness in men.

There is no difference in identifying the causes of schizophrenia. As with depression, stress or daily stress is also the most valued factor as a cause of schizophrenia, so are male and female respondents. This is in line with research by Jorm, et al. (1997b) that daily stress is the most valued factor as a cause of schizophrenia. Other results, namely biological factors, are more often assessed as causes of schizophrenia than depression, in line with the results of Jorm, et al. (1997b).

Further results show that there are differences in attitudes towards expert assistance in depression based on the gender of the respondent and the vignette figure. The differences in attitudes towards expert assistance in depression based on the gender of respondents and figures are in line with the research of Wang, et al (2007). Wang, et al. (2007: 447) argued that the existence of this gender difference might be related to the lower prevalence of depression in men and due to the lack of exposure to the disorder. 
Lack of exposure results in a lack of awareness and knowledge which can contribute to low levels of assistance seeking. The low level of seeking help can also be related to personal weaknesses that tend to be considered men as a cause of depression (Wang, et al., 2015). The search for emotional assistance for mental health problems for men is also a sign of weakness and is contradicted by masculinity as well as fears of stigma that can be a reason why men choose not to seek psychological help (Wong, 2016 and Holzinger, et al., 2012).

The pattern of seeking expert assistance for mental health problems in the campus environment is still hampered due to the influence of negative stigma (Vidourek, et al., 2014; Holland \& Wheeler, 2016) and lack of mental health literacy, let alone help for depression which is still widely associated with personal weakness. This is proven by the fact that there are still many respondents, especially men who consider expert assistance to be less important for depression.

Further results show that there is no difference in attitude towards expert assistance in schizophrenia based on the gender of respondents and vignette figures. Almost all respondents agreed if schizophrenics get expert assistance related to mental disorders suffered, both male and female figures. These results are consistent with Jorm, et al. (1997b) and Gibbons, Thorsteinsson, \& Loi (2015) studies which state that expert assistance is more positive for schizophrenics than depression. One logical reason is that depression is more common and is more often associated with non-medical conditions such as fatigue and stress whose handling does not require expert help, unlike schizophrenia which describes more severe and less common mental conditions (Jorm, et al, 1997b).

\section{Conclusion}

From this study we can conclude that there is no difference in the ability to recognize depression and schizophrenia based on the respondent's gender and the gender of the vignette figure. However, there are differences in knowledge about the cause of depression based on gender where the environmental factors and trauma are identified as a prominent cause of depression in female figures while biological factors and personal weaknesses are more pronounced in male figures. There are also differences in positive attitudes towards expert assistance for depression based on the gender of respondents and figures, where more male respondents do not recommend expert help and it is not necessary for male character to seek expert help for depression.

Based on these conclusions, we can give several suggestions: 1) For mental health experts, the results of the analysis showed that men are more likely not to recommend seeking expert help related to depression and this can be influenced by negative stigma embedded within the society, as it is considered a sign of weakness that indicates less masculinity. For this reason, men are needs to be specifically targeted in efforts to improve mental health literacy, to help them reach appropriate assistance, and to reduce the negative stigma surrounding men and mental disorder. 2) For the university, the campus environment is a place where students spend a lot of time. For this reason, the campus can be an ideal place for students to improve mental health literacy by conducting campaigns, interventions that involve reducing the negative stigma of mental disorders, designing a curriculum that can increase mental health awareness, as well as providing mental health facilities that can be reached by the students. 


\section{Coping Strategy and Psychological Well-being \\ Yuni Syaudah}

\section{References}

Atzmüller, C., \& Steiner, P.M. (2010). Experimental vignette studies in survey research. Methodology European Journal of Research Methods for the Behavioral and Social Sciences, 6(3), 128-138. doi:10.1027/1614-2241/a000014

Azwar, S. (2018). Metode Penelitian Psikologi (Edisi II). Yogyakarta: Pustaka Pelajar.

Badan Penelitian dan Pengembangan Kesehatan. (2013). Riset Kesehatan Dasar (RISKESDAS) 2013. Kementerian Kesehatan, Jakarta.

Bener, A., \& Ghuloum, S. (2010). Gender differences in the knowledge, attitude and practice towards mental health illness in a rapidly developing Arab society. International Journal of Social Psychiatry, 57(5), 480-486. doi:10.1177/0020764010374415

Biddle, L., Donovan, J., Sharp, D., \& Gunnell, D. (2007). Explaining nonhelp-seeking amongst young adults with mental distress: a dynamic interpretive model of illness behavior. Sociology of Health \& Illness, 29(7), 983-1002. doi:10.1111/j.14679566.2007.01030.x

Chang, C. (2008). Increasing mental health literacy via narrative advertising. Journal of Health Communication, 13 , $37-55$. doi:10.1080/10810730701807027

Cotton, S.M., Wright, A., Harris, M.G., \& Jorm, A.F. (2006). Influence of gender on mental health literacy in young Australians. Australian and New Zealand Journal of Psychiatry, 40, 790-796. doi:10.1080/j.14401614.2006.01885.x

Diaz-Granados, N., \& Stewart, D.E. (2007). Using a gender lens to monitor mental health. International Journal of Public Health, 52, 197198. doi:10.1007/s00038-007-02172

Ellis, L. A., Collin, P., Hurley, P. J., Davenport, T. A., Burns, J. M., \& Hickie, I. B. (2013). Young men's attitudes and behaviour in relation to mental health and technology: Implications for the development of online mental health services. BMC Psychiatry, 13, 119. doi:10.1186/1471-244X-13-119.

Fakih, M. (2013). Analisis Gender \& Transformasi Sosial. Yogyakarta: Pustaka Pelajar.

Farrer, L., Griffiths, K.M., Leach, L.S., \& Christensen, H. (2008). Age differences in mental health literacy. BMC Public Health, 8. doi:10.1186/1471-2458-8-125

Furnham, A., \& Swami, V. (2018). Mental health literacy: A review of what it is and why it matters. International Perspectives in Psychology: Research, Practice, Consultation, 7(4), 240-257. doi:10.1037/ipp0000094

Gibbons, R.J., Thorsteinsson, E.B., Loi, N.M. (2015). Beliefs and attitudes towards mental illness: an examination of the sex differences in mental health literacy in a community sample. PeerJ, 3, e1004. doi:10.7717/peerj.1004

Hadjimina, E., \& Furnham, A. (2017). Influence of age and gender differences on mental health literacy of anxiety disorders. Psychiatry Research, 251, 8-13. doi:10.1016/j.psychres.2017.01.089

Holland, D., \& Wheeler, H. (2016). College student stress and mental health: examination of stigmatic views on mental health counseling. 
Michigan Sociological Review, 30, 16-34.

Holzinger, A., Floris, F., Schomerus, G., Carta, M. G., \& Angermeyer, M. C. (2012). Gender differences in public beliefs and attitudes about mental disorder in western countries: A systematic review of population studies. Epidemiology and Psychiatric Sciences, 21, 73-85. doi:10.1017/s2045796011000552

Hox, J.J., Kreft, I.G.G., \& Hermkens, L.J. (1991). The Analysis of Factorial Surveys. Sociological Methods \& Research, 19, 493-510. doi:10.1177/0049124191019004003

Hunt, J., \& Eisenberg, D. (2010). Mental health problems and help-seeking behavior among college students. Journal of Adolescent Health, 46, 310.

doi:10.1016/j.jadohealth.2009.08.00 8

Jorm, A.F., Korten, A.E., Jacomb, P.A., Christensen, H., Rodgers, B., \& Pollitt, P. (1997a). "Mental health literacy": a survey of the public's ability to recognise mental disorders and their beliefs about the effectiveness of treatment. The Medical Journal of Australia, 166(4). doi:10.5694/j.1326-

5377.1997.tb140071.x

Jorm, A.F., Korten, A.E., Jacomb, P.A., Christensen, H., Rodgers, B., \& Pollitt, P. (1997b). Public beliefs about causes and risk factors for depression and schizophrenia. Social Psychiatry and Psychiatric Epidemiology, 32, 143-148. doi:10.1007/BF00794613

Jorm, A.F. (2012). Mental health literacy: Empowering the community to take action for better mental health. American Psychologist, 67(3), 1-13. doi:10.1037/a0025957
Lauber, C., Nordt, C., Falcato, L., \& Rössler, W. (2003). Do people recognise mental illness? Factors influencing mental health literacy. European Archives of Psychiatry and Clinical Neurosciences, 253, 248-251. doi:10.1007/s00406-0030439-0

Leighton, S. (2010). Using a vignettebased questionnaire to explore adolescents' understanding of mental health issues. Clinical Child Psychology and Psychiatry, 15(2) 231-250. doi:10.1177/1359104509340234

Marcus, M., \& Westra, H. (2012). Mental health literacy in Canadian young adults: results of a national survey. Canadian Journal of Community Mental Health, 31(1). doi:10.7870/cjcmh-2012-0002

Novianty, A., \& Hadjam, M.N.R. (2017). Literasi kesehatan mental dan sikap komunitas sebagai prediktor pencarian pertolongan formal. Jurnal Psikologi, 44(1), 50-65. doi:10.22146/jpsi.22988

Pangkalan Data Pendidikan Tinggi Kementerian Riset, Teknologi Dan Pendidikan Tinggi. https:/ / forlap.ristekdikti.go.id. Accessed 23 March 2019.

Reavley, N., McCann, T., \& Jorm, A.F. (2012). Mental health literacy in higher education students. Early Intervention in Psychiatry, 6, 45-52. doi:10.1111/j.1751-

7893.2011.00314.x

Vidourek, R., King, K., Nabors, L., Lynch, A., \& Merianos, A. (2014). College students' perceived confidence in mental health help-seeking. International Journal of Mental Health Promotion, 16(2), 83-90. doi:10.1080/14623730.2014.892257 
Wang, J., Adair, C., Fick, G., Lai, D., Evans, B., Perry, B.W., Jorm, A., Addington, D. (2007). Depression literacy in Alberta: Findings from a general population sample. The Canadian Journal of Psychiatry, 52(7), 442-449. doi:10.1177/070674370705200706

Wong, K. (2016). Gender differences in mental health literacy of university students. Western Undergraduate Psychology Journal, 4(1). 